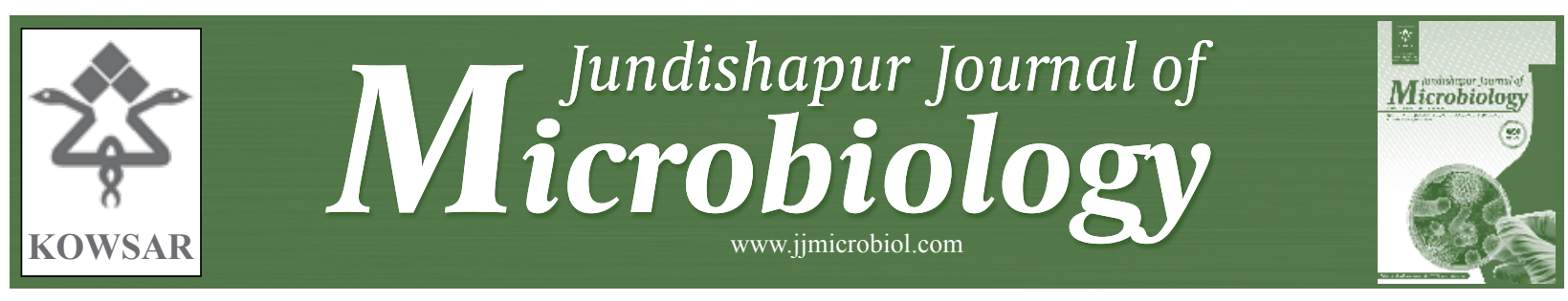

\title{
Fungal and Bacterial Contamination on Indoor Surfaces of a Hospital in Mexico
}

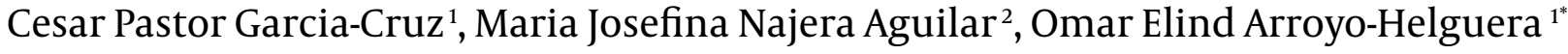 \\ ${ }^{1}$ Institute of Public Health, Universidad Veracruzana, Luis Ayala Avenue Castelazo S / N. Xalapa, Veracruz, Mexico.C.P. 91020, Mexico \\ ${ }^{2}$ Xalapa ISSSTE Hospital Clinic, Esq Fraternity Jose Hernandez, Col. Obrero Campesina C.P. 91020, Xalapa, Veracruz, Mexico
}

\begin{tabular}{l}
\hline A R T I C L E I N F O \\
\hline Article type: \\
Original Article \\
\hline Article history: \\
Received: 06 Oct 2011 \\
Revised: 01 Jan 2012 \\
Accepted: 12 Jan 2012
\end{tabular}

Keywords:

Bacteria

Fungi

Yeasts

Cross Infection

\begin{abstract}
A B S T R A C T
Background: Nosocomial infections acquired during hospitalization depend on the characteristics of the microorganisms, with a high risk of these being acquired when the environment is contaminated. Cross-transmission of microorganisms by contaminated surfaces and the hands of health care workers are considered to be the main route of the spread of nosocomial infections and in many Mexican hospitals, information about microbial and fungi contaminants on indoor surfaces is insufficient.

objectives: In this study, we explore the bacterial and fungal genera present on surfaces taken from; armrest beds, wash sinks, medical tables, and the hands of medical staff from emergency, intensive care unit, inhalation therapy, stomatology and pediatric areas.

Materials and Methods: The present study was conducted in a hospital located in Xalapa City in Mexico; the samples were taken during a 6 month period from August to December, 2010. Surface swab specimens were collected from predefined surfaces with cotton tipped applicators, pre-moistened with sterile saline and inoculated on Sabouraud dextrose or selective Eosin-Methylene Blue agar plates and incubated for 1 to 7 days at $28^{\circ} \mathrm{C}$ or $37^{\circ} \mathrm{C}$ in three triplications in order to isolate bacterial and fungal contaminants. Results: We isolated and identified gram-negative bacteria and fungi and the results showed that the predominant bacteria were; Klebsiella spp. Pseudomonas spp. and E coli spp. The predominant genera of fungi were; Cladosporium spp. Microsporum canis., Aspergillus spp. and Penicillium spp.

Conclusions: This study showed that all areas of the hospital have pathogenic fungi and bacteria, indicating that these are a potential source of cross-infection from the hands of health care workers to their patients.
\end{abstract}

Copyright $\odot 2012$ Kowsar Corp. All rights reserved.

-Implication for health policy/practice/research/medical education:

Identification of bacterial and fungal contamination in indoor surfaces would be the key elements in order to evaluate the effectiveness of aseptic techniques that can be applied and contribute to better preventive measures against infectious diseases caused by nosocomial pathogens.

Please cite this paper as:

Garcia-Cruz CP, Najera Aguilar MJ, Arroyo-Helguera OE. Fungal and Bacterial Contamination on Indoor Surfaces of a Hospital in Mexico. Jundishapur J Microbiol. 2012;5(3):460-4. DOI: 10.5812/jjm.2625

* Corresponding author: Omar Elind Arroyo Helguera, Institute of Public Health, Universidad Veracruzana, Av. Luis Castelazo Ayala S/N, Industrial Animas, Xalapa, Veracruz, Mexico. Tel: + 22-88418933, Fax: + 22-88418934, Email: oarroyo@uv.mx; E-mail: omarelind20@hotmail.com

DOI:10.5812/jjm.2625

Copyright $\odot 2012$ Kowsar Corp. All rights reserved.

\section{Background}

Nosocomial infections acquired during hospitalization depend on the characteristics of the microorganisms, with a high risk of being acquired when the healthcare environment is contaminated (1). The most common pathogen transference occurs between the hands of health professionals and patients or by the presence of bacteria and fun- 
gi on inanimate surfaces and equipment (2). Previous data have shown that drug resistant bacteria and fungi strains are of interest in hospitals (3). On the other hand, hospitals have the potential for pathogen spread because they have contact with; medical furniture, instruments, clothing, skin, physical facilities, air, medical staff and drainage, although the infections caused by such nosocomial pathogens involves a contaminated environment which should have applied strict safety biosecurity procedures (3). A significant proportion of hospital infections result from crosscontamination and transmission of microorganisms from; surfaces, hands of health care workers and medical equipment which has become contaminated with a variety of pathogenic and nonpathogenic organisms (4-6).

Common human pathogens, such as Escherichia coli, Enterococcus spp, Acinetobacter spp, Staphylococcus aureus and noroviruses can survive for long periods on hospital surfaces or fomites that can potentially transmit infectious organisms (5). In addition to this, several studies have shown that hospital infections are also caused by fungi, such as Candida spp and various species of Aspergillus, Cladosporium and Penicillium $(7,8)$. Even in samples from the ventilator system (HEPA filter and common filter), air canal, air and hospital instruments, fungi such as Penicillium, Aspergillus, Cladosporium, Trichoderma, Stereptomyses, Chrysosporium and Rhizopus have been isolated (9).

Therefore it is important to know the presence of these pathogens in different areas of a hospital and to implement monitoring programs in order to evaluate the effectiveness of aseptic techniques that can be applied and contribute to better preventive measures against infectious diseases caused by nosocomial pathogens. In Mexican hospitals there is little information about the prevalence of bacteria and fungi.

\section{Objectives}

The principal goal of this study is to investigate the presence of bacteria and fungi on the surfaces in different areas of a public hospital in Mexico.

\section{Materials and Methods}

\subsection{Methodology}

The present study was carried out in Xalapa City in Mexico, in 4 areas of the ISSSTE(Instituto de Seguridad y Servicios Sociales de los Trabajadores del Estado) public hospital; emergency, intensive care unit (ICU), inhalation therapy, stomatology and pediatric areas. The samples were taken during a 6 month period from August to December 2010. All medical staff involved in this study granted their informed consent to participate.

\subsection{Sampling}

Surface swab specimens were collected from predefined surfaces (armrest beds, wash sinks, medical tables, and the hands of medical staff) with cotton tipped applicators pre-moistened with sterile saline from; emergency, intensive care unit (ICU), inhalation therapy, stomatology and pediatric wards of the hospital. The swabs were immediately inoculated onto plates that contained Sabouraud dextrose agar plus $50 \mu \mathrm{g} / \mathrm{mL}$ of chloramphenicol (Fisher, USA) for the growth of fungi and yeast or on plates with selective Eosin-Methylene Blue agar (EMB), agar medium (Fisher, USA) (peptone 10g, lactose 5g, sucrose 5g, dipotassium phosphate $2 \mathrm{~g}$, agar $13.5 \mathrm{~g}$, Eosin $0.4 \mathrm{~g}$ and Methylene blue $0.065 \mathrm{~g}$ ) for the growth of gram-negative bacteria. All samples were incubated for a 1 to 7 day period at $28^{\circ} \mathrm{C}$ or $37^{\circ} \mathrm{C}$ in three triplications.

\subsection{Fungal Identification}

All samples were incubated at $28^{\circ} \mathrm{C}$ and checked daily for fungal growth during the 7 days in order to determine the number of colony forming units per $\mathrm{m}^{2}\left(\mathrm{CFU} \mathrm{m}^{2}\right)$. Fungi and yeast considered to have a distinct morphologically were isolated. Identification was made according to their macroscopic and microscopic morphological characteristics of the vegetative mycelium and the reproductive structures by standard mycological methods. Candida yeasts were identified on plates with CHROMagar $^{\mathrm{TM}}$ (CHROMagar Microbiology, France), according to the manufacturers. Chi-square tests were used for the statistical analyses.

\subsection{Bacterial Identification}

The samples from the surfaces were inoculated onto specific plates with EMB in order to detect gram negative bacteria, then they were transferred to the laboratory and kept in incubators for $72 \mathrm{~h}$ and the number of CFU $\mathrm{m}^{2} \mathrm{un}$ der a temperature of $35^{\circ} \mathrm{C}$ was determined. Identification was determined following a series of biochemical tests included gram staining, tests for oxidase, methyl red, catalase activity, lactose fermentation, casein hydrolysis and sugar fermentation(10). The findings were registered in data sheets during each phase of the study. Chi-square tests were used for the statistical analyses.

\section{Results}

Bacteria and fungi were present in different areas of the hospital. Of the 1838 plates obtained from samples from; wards, surfaces and the hands of medical staff, a total frequency were identified in each investigation area of the hospital and these are shown in Table 1 and Figure 1. The results from the surface swab samples indicate that the bacteria recovered produced a low count of colony-forming units. In all of the positive sampled areas, we found $50.45 \%$ of Klebsiella and 32 \% of Pseudomona spp were detected predominantly in the wash sink and medical table surfaces, followed by E coli spp. (9.17\%) and Enterobacter spp. (8.25\%). Of the surfaces that were swabbed, those 


\begin{tabular}{|c|c|c|c|c|c|c|c|}
\hline Genera & $\begin{array}{l}\text { Emergency, } \\
\mathrm{CFU} / \mathbf{m}^{2}\end{array}$ & $\mathrm{ICU}, \mathrm{CFU} / \mathrm{m}^{2}$ & $\begin{array}{l}\text { Inhalation } \\
\text { Therapy, } \mathbf{C F U} / \mathbf{m}^{2}\end{array}$ & $\begin{array}{l}\text { Pediatric, } \\
\mathrm{CFU} / \mathrm{m}^{2}\end{array}$ & $\begin{array}{l}\text { Stomatology, } \\
\text { CFU } / \mathbf{m}^{2}\end{array}$ & Total CFU $/ \mathrm{m}^{2}$ & Total, \% \\
\hline Klebsiella spp. & 27 & 4 & - & 13 & 11 & 55 & 50.4 \\
\hline E-coli spp. & 5 & - & - & 3 & 2 & 10 & 9.17 \\
\hline Enterobacter spp. & 3 & 6 & - & - & - & 9 & 8.2 \\
\hline Pseudomona spp. & 7 & 9 & - & 11 & 8 & 35 & 32.1 \\
\hline Total & 42 & 19 & - & 26 & 21 & 109 & 100 \\
\hline
\end{tabular}

Figure 1. Bacterial Genera Present in Surface Samples from Emergency, Intensive Care Unit, Inhalation Therapy, Stomatology and Pediatric Areas

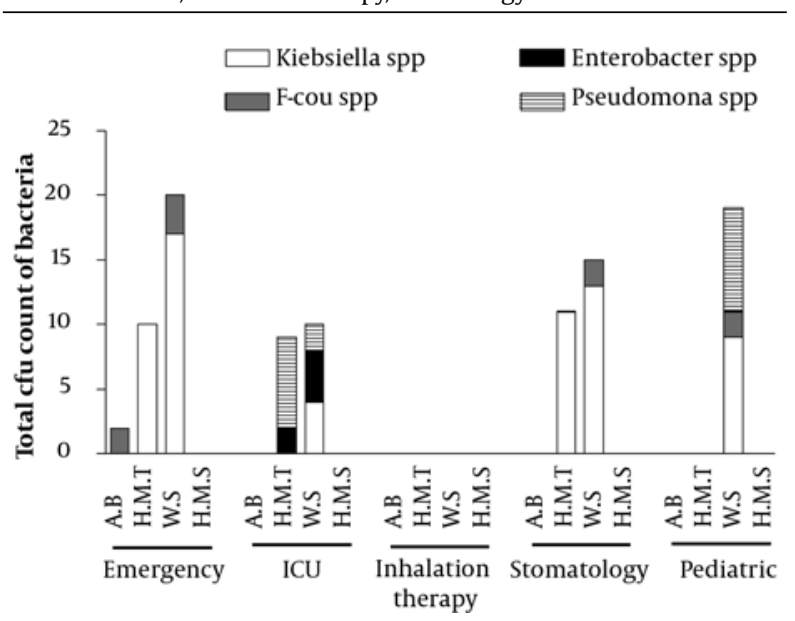

a Abbreviations: A.B: Armrest beds; H.M.T: Medical tables; W.S: Wash sink; H.M.S: Hands of medical staff.

${ }^{\mathrm{b}}$ All samples were incubated for 72 hours at $37^{\circ} \mathrm{C}$ in three triplications

least contaminated were the armrest bed surface and the hands of the medical staff. The total concentration of bacteria was highest (38.5\%) in the emergency area, followed by stomatology $(23.85 \%)$, pediatrics (19.26 \%) and ICU (17.43\%) areas. The predominant bacterium recovered was Klebsiella spp. with $50.45 \%$ of total bacteria, followed by Pseudomona spp. with $32.11 \%$, E coli spp. with $9.17 \%$ and Enterobacter spp. with $8.25 \%$. The inhalation therapy area is a new zone in the hospital where few bacteria were found.

The fungi most commonly recovered from the surfaces of the hospital were as follows (Table 2). The emergency area was the most contaminated with $51.18 \%$ of total fungi, followed by ICU (19.68\%) and pediatric areas (14.96\%), and the least contaminated were the inhalation therapy (7.87 $\%)$ and stomatology (6.29 \%) areas. The principal fungi found were Cladosporium spp. (29.92\%), Microsporum spp. (25.19\%), Aspergillus spp. (17.32\%), Penicillium spp. (13.38 $\%)$ and Candida spp. (14.1\%) on all of the surfaces studied. Cladosporium spp and Aspergillus spp. were recovered in four of the areas investigated, followed by Microsporum canis, and Candida spp. This trend appeared principally in the emergency, inhalation therapy and ICU areas, indicating that these fungi are the major genera found in the hospital. In Figure 2 we show that from the medical tables and the hands of the medical staff Cladosporium

Figure 2. Fungal and Yeast Genera Present on Surface Samples from Emergency, Intensive Care Unit, Inhalation Therapy, Stomatology and Pediatric areas

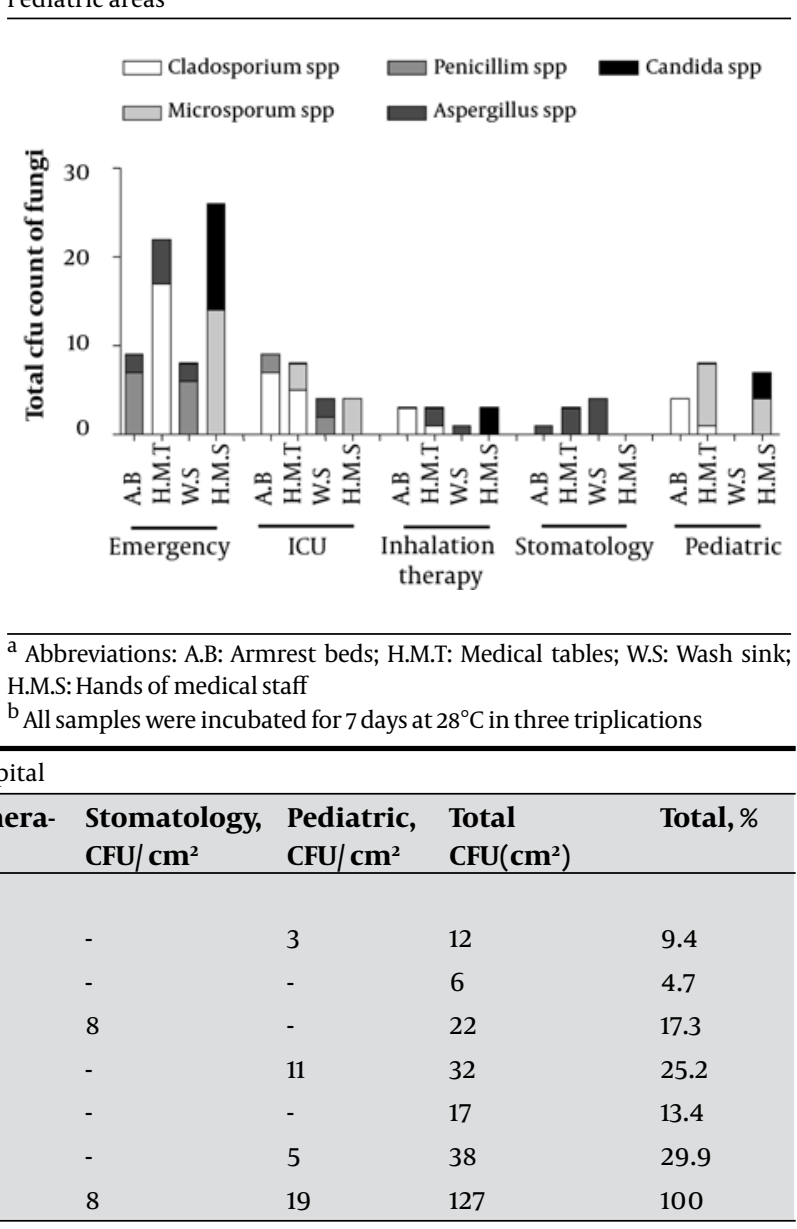


spp. Microsporum canis., Candida spp. and Aspergillus spp. were recovered, while on the armrests of the beds and in the wash sink Penicillium spp. Aspergillus spp. and Microsporum spp. were the most commonly found fungi.

\section{Discussion}

The hospital environment is contaminated with a variety of pathogenic and nonpathogenic microorganisms that can persist on surfaces for prolonged periods. Numerous studies have demonstrated that the hands and gloves of healthcare workers readily acquire pathogens after coming into contact with contaminated hospital surfaces and they can subsequently transfer these organisms to the patients and inanimate surfaces that they touch. The results of the surface sampling, demonstrated that the hospital environment is a potential reservoir of bacteria such as; Pseudomonas spp. Klebsiella spp. E coli spp. and Enterobacter spp. and this is in accordance with other studies (11). E coli are the most common gram-negative bacterium, causing mainly urinary tract infections (12). Pseudomona aeruginosa is also very common, chiefly causing lower respiratory tract infections (13). Of great significance is the finding that even the medical tables or hands of the medical staffs which are disinfected daily, were found to be colonized by bacteria and fungi. The frequency of the bacteria varied but the major varieties of bacteria identified were Klebsiella spp. and Pseudomonas spp. found primarily in the emergency, stomatology and pediatric areas, although in the ICU the samples were predominantly Pseudomona spp. and Enterobacter spp. Previous studies have shown that nurses can contaminate their hands with Klebsiella spp. during "clean activities" (14), Enterobacter spp. and Klebsiella spp. are the most commonly nosocomial infections acquired and this seems to be a problem in community hospitals $(5,15)$. These results indicate that all surfaces swabbed in the hospital may increase the number of nosocomial infections and therefore the length of stay exceeds the average of 15 days, as stated in the guidelines on the management of multidrug resistant organisms in health care settings (16).

In this study the predominant fungi were Cladosporium spp. Aspergillus spp. Penicillium spp and Microsporum canis, which is in accordance with other studies $(11,17)$. Microsporum is a fungus that is not commonly found on surfaces in hospitals, however, this fungus is found in a wide range of environments both indoors and outdoors. The natural habitat of some of the Microsporum spp. is in the soil (the geophilic species); others primarily affect various animals (the zoophilic species) or humans (the anthropophilic species). The causative agents of tinea capitis in the urban areas of Mèxico are Microsporum canis and Trichophyton tonsurans. In a clinical and mycological study of 125 cases in Mexico City, Microsporum canis has been isolated in 75 (61.5\%) and Trichophyton tonsurans in 36 cases $(29.5 \%)$. Tinea capitis occurs predominantly in ru- ral or suburban areas and some of the factors associated with this increased frequency include; poor personal hygiene, overcrowding, and low socioeconomic level. In this study we showed the presence of Candida spp. on the medical tables and on the hands of the medical staff, it is known that these yeast can survive on surfaces for up to 150 days and are involved in the development of; septicemia, urinary tract infections and surgical-site infections, among critically ill patients in the last decades $(18,19)$.

Contamination could be reduced with the act of washing hands before and after contact with both patients and the various surfaces. However, health professionals' adherence to this practice has been reported to be less than $50 \%$ in general health facilities (20). Intensifying cleaning routines would reduce the dissemination of pathogens. More attention should be given to the adequacy of the length, the frequency and specific care when cleaning surfaces, because removing dirty areas is important in reducing biofilms. We found bacteria and fungi mainly on the hands of the medical staff, and on surfaces such as armrest beds, wash sink and medical tables; these data corroborated the hypothesis that the surfaces that are touched most often are more contaminated $(10,21)$. In addition to the traffic of people; health staff and visitors, in the different areas and the contact with patients, objects, equipment and any surface that facilitates the spread of bacteria, fungi, and pathogens if precautions are not observed, especially with hand washing.

This study has shown that all areas of the hospital carry pathogenic fungi and bacteria. There is no evidence that the fungi and bacteria on the analyzed surfaces caused infection. However, it must be of concern that almost all of the surfaces were contaminated with fungi and bacteria and are a potential source of cross-infection from the hands of the health care workers to their patients. Further possible investigations should include examining the effect of hand antisepsis or decontamination of surfaces in order to determine whether cleaning these potential sources of infection are associated with a reduced incidence of infection in a hospital.

\section{Ackowledgements}

This study had financial support from PROMEP-SEP grant No. PROMEP/103.5/10/5006 and ISP-UV POA-2010-2011 grants. The authors also wish to thank Irene Xochihua Rosas for his contribution to this study and for proofreading.

\section{Financial Disclosure}

The author declares that the research was conducted in the absence of any commercial or financial relationships that could be construed as a potential conflict of interest.

\section{Funding/Support}

This study had financial support from PROMEP-SEP 
grant No. PROMEP/103.5/10/5006 and ISP-UV POA-20102011 grants.

\section{References}

1. Medina M, Martinez-Gallego G, Sillero-Arenas M, Delgado-Rodriguez M. [Risk factors and length of stay attributable to hospital infections of the urinary tract in general surgery patients]. Enferm Infecc Microbiol Clin. 1997;15(6):310-4.

2. Kayabas U, Bayraktar M, Otlu B, Ugras M, Ersoy Y, Bayindir Y, et al. An outbreak of Pseudomonas aeruginosa because of inadequate disinfection procedures in a urology unit: a pulsed-field gel electrophoresis-based epidemiologic study. Am J Infect Control. 2008;36(1):33-8.

3. Mazzali M, Jefferson JA, Ni Z, Vaziri ND, Johnson RJ. Microvascular and tubulointerstitial injury associated with chronic hypoxiainduced hypertension. Kidney Int. 2003;63(6):2088-93.

4. Bauer TM, Ofner E, Just HM, Just H, Daschner FD. An epidemiological study assessing the relative importance of airborne and direct contact transmission of microorganisms in a medical intensive care unit. J Hosp Infect. 1990;15(4):301-9.

5. Kramer A, Schwebke I, Kampf G. How long do nosocomial pathogens persist on inanimate surfaces? A systematic review. BMC Infect Dis. 2006;6:130.

6. Sehulster L, Chinn RY. Guidelines for environmental infection control in health-care facilities. Recommendations of CDC and the Healthcare Infection Control Practices Advisory Committee (HICPAC). MMWR Recomm Rep. 2003;52(RR-10):1-42.

7. Faure O, Fricker-Hidalgo H, Lebeau B, Mallaret MR, AmbroiseThomas P, Grillot R. Eight-year surveillance of environmental fungal contamination in hospital operating rooms and haematological units. J Hosp Infect. 2002;50(2):155-60.

8. Lajonchere JP, Feuilhade de Chauvin M. [Contamination by aspergillosis: evaluation of preventive measures and monitoring of the environment]. Pathol Biol (Paris). 1994;42(7):718-29.

9. Hashemi SJ, Sarasgani MR, Zomorodian K. A comparative survey of serum androgenic hormones levels between male patients with dermatophytosis and normal subjects. Jpn J Infect Dis. 2004;57(2):60-2.
10. Lemmen SW, Hafner H, Zolldann D, Stanzel S, Lutticken R. Distribution of multi-resistant Gram-negative versus Gram-positive bacteria in the hospital inanimate environment. J Hosp Infect. 2004;56(3):191-7.

11. Li JT, Li Y, Wang J. [Surveillance on gram-positive bacteria isolated from patients with hospital acquired infections or community acquired infections]. Zhonghua Yi Xue Za Zhi. 2003;83(5):365-74.

12. Kim JM, Park ES, Jeong JS, Kim KM, Oh HS, Yoon SW, et al. Multicenter surveillance study for nosocomial infections in major hospitals in Korea. Nosocomial Infection Surveillance Committee of the Korean Society for Nosocomial Infection Control. Am J Infect Control. 2000;28(6):454-8.

13. Richards MJ, Edwards JR, Culver DH, Gaynes RP. Nosocomial infections in medical intensive care units in the United States. National Nosocomial Infections Surveillance System. Crit Care Med. 1999;27(5):887-92.

14. Casewell M, Phillips I. Hands as route of transmission for Klebsiella species. Br Med J.1977;2(6098):1315-7.

15. Haddy RI, Cecil ML, Norris LL, Markert RJ. Enterobacter bacteremia in the community hospital. J Fam Pract.1991;32(6):601-6.

16. Sehulster LM. Prion inactivation and medical instrument reprocessing: challenges facing healthcare facilities. Infect Control Hosp Epidemiol. 2004;25(4):276-9.

17. Santos PE, Cordoba S, Carrillo-Munoz A, Rodero L, Rubeglio E, Soria M. [Epidemiology of fungaemia in a paediatric hospital of high complexity]. Rev Iberoam Micol. 2010;27(4):200-2.

18. Eggimann P, Garbino J, Pittet D. Management of Candida species infections in critically ill patients. Lancet Infect Dis. 2003;3(12):772-85.

19. Eggimann P, Garbino J, Pittet D. Epidemiology of Candida species infections in critically ill non-immunosuppressed patients. Lancet Infect Dis. 2003;3(11):685-702.

20. Ascioglu S, Rex JH, de Pauw B, Bennett JE, Bille J, Crokaert F, et al. Defining opportunistic invasive fungal infections in immunocompromised patients with cancer and hematopoietic stem cell transplants: an international consensus. Clin Infect Dis. 2002;34(1):7-14.

21. Hayden MK, Bonten MJ, Blom DW, Lyle EA, van de Vijver DA, Weinstein RA. Reduction in acquisition of vancomycin-resistant enterococcus after enforcement of routine environmental cleaning measures. Clin Infect Dis. 2006;42(11):1552-60. 